\title{
Effect of different sources of organic manure on growth and yield of sweet pepper
}

\begin{abstract}
Indiscriminate use of chemical fertilizers is a common practice which is hazardous both for soil health and environment. It has been more than three decades that the global agriculture has been depicted towards organic agriculture owing to sustainability and reduced environmental effects. A pot experiment was conducted at IAAS, Lamjung Campus to study the effect of various surces of organic manure on the growth and yield of sweet pepper. The experiment was conducted in Complete Randomized Design using 7 treatments replicated thrice. Each treatment consist of single pot with single plant. The treatments used were; Control, Chemical fertilizer, Vermi-compost, Poultry manure, Farm yard manure, Goat manure and Commercial organic fertilizer. Effect of different treatments on growth and yield of sweet pepper was affected significantly. The results revealed better growth and yield performance by vermi-compost followed by poultry manure over control and FYM. Chemical fertilizers, however, had similar yield as the previous mentioned treatments, but was slow in its flowering and fruiting behavior
\end{abstract}

Keywords: sweet pepper, organic manures, vermi-compost, goat manure, poultry manure, chemical fertilizer, farm yard manure, soil health, capsicum annum, cash crop, green pepper, capsaicin, vitamin c, polyphenols, chlorophylls, carotenoids, sugars
Volume 3 Issue 5 - 2016

\author{
Adhikari P, Khanal A, Subedi R \\ Department of Agriculture, Institute of Agriculture and Animal \\ Science, Nepal
}

Correspondence: Adhikari P, Department of Agriculture, Institute of Agriculture and Animal Science, Lamjung Campus, Nepal,Email paruladhikari.iaas@gmail.com

Received: February 01, 2016 | Published: May 17, 2016

\section{Introduction}

Capsicum (Capsicum annum) commonly known as Bell pepper or Sweet pepper or Green pepper belongs to family Solanaceae and is native to Mexico with secondary center of origin at Guatemala and Bulgaria. ${ }^{1}$ Sweet peppers differ from common hot peppers in size and shape of the fruits, capsaicin content and usage. The fruits are nonpungent and have been widely used in immature or green stage as vegetable for stuffing or for salads. Considered as high cash crop, it has occupied an important rank in world agriculture due to its high profit and nutritional values for human health. Sweet pepper fruits are a rich source of vitamin $\mathrm{C}$, polyphenols, chlorophylls, carotenoids, sugars, ${ }^{2}$ magnesium, calcium, potassium, phosphorus and iron. ${ }^{3}$ The environmental conditions in the mid hills of Nepal are very conducive for producing excellent quality fruits of bell pepper. ${ }^{4}$

Application of chemical fertilizers alone can supply only one or two nutrient elements to the crop. On the other hand, supplying only organic inputs can improve soil physical and biological environment but suffers from drawback of low content of plant nutrients. However, in the modern days, when agriculture is motivated not only for production, but also accounts for the sustainability of all the resources including soil for the generations to come. The use of chemical fertilizers has been many-a-times reported for degrading soil and water resources. Moreover, organic farming is both a philosophy and a system of agriculture, ${ }^{5}$ which avoids or largely excludes the use of synthetically produced fertilizers, pesticides and to the maximum extent possible relies upon crop rotations, crop residues, animal manures, legumes, green manures, off farm organic wastes, mineral bearing rocks and bio-fertilizers to maintain soil productivity and to supply plant nutrients and biological means to control insects, weeds and other pests. Thus, this experiment was carried out in order to study the effect of various sources of plant nutrients on growth, development and yield of sweet pepper and to compare the nutrient value of various sources of organic manure used in production of sweet pepper.

\section{Materials and methods}

The research was carried out in pots at Lamjung Campus, IAAS during 2015 at an altitude of 625 masl. The pot media was made my mixing soil collected from upland orchard mixed with the amount of various sources of organic manure as per the treatment. The experiment was carried out in Complete Randomized Design (CRD) with 7 treatments replicated thrice. The treatments consisted different sources of organic manure compared to that of untreated control and chemical fertilizer. The different sourcs of organic manure used were Poultry manure, Goat anure, Vermi-compost, farm yard manure and Commercially available Organic fertilizer. Weeding, crop management and harvesting was done manually. Various growth and yield attributes were examined at various times of crop cycle.

\section{Results and discussion}

The analysis of data obtained from the experiment showed varied response of the plant nutrient materials applied to the crop (Table 1).

\section{Days to first flowering}

Days to first flowering was significantly acclerated by poultry manure and vermicompost, which was significantly rapid than the other treatments. This is a profound phenomenon exhibited for a 
longer indeterminant reproductive growth which ultimately aids to the overall fresh pepper yield. Moreover, FYM produced the flowers significantly earlier than that by commercial organic fertilizer and control, both of which were better than chemical fertilizer. Chemical fertilizers tend to provide the plant nutrients readily and encourage vegetative growth, thereby, delaying the flowering phenomenon in sweet pepper.

\section{Days to first harvest}

The result of the experiment for the days to first harvest did not follow the exact trends of the days to first flowering. Use of poultry manure and vermicompost resulted in similar days to first harvest, which were significantly earlier than rest of the treatments, except that resulting from use of FYM. FYM, however, was found to be similar to contol and goat manure in its influence in the days to first harvest, but was significantly early than chemical fertilizer and commercial organic fertilizer.

\section{Plant height}

Application of various manures and fertilizers showed varied influence on the final attainable plant height. Plant height obtained from application of poultry manure and vermicompost were similar, both of which were significantly taller than the ones produced by other treatment. All the other treatment produced plant height similar to each other.

Table I Effect of various treatments used on phenological and morphological parameters of sweet pepper

\begin{tabular}{lllll}
\hline Treatment & Days to 1st flower & Days to 1st harvest & Plant height at harvest (cm) & Stem diameter (cm) \\
\hline C & $50 \mathrm{c}$ & $72 \mathrm{bcd}$ & $28.3 \mathrm{~b}$ & $6.1 \mathrm{c}$ \\
CF & $60 \mathrm{~d}$ & $80 \mathrm{~d}$ & $28.8 \mathrm{~b}$ & $7.7 \mathrm{c}$ \\
VC & $26 \mathrm{a}$ & $54 \mathrm{a}$ & $38.5 \mathrm{a}$ & $11.0 \mathrm{ab}$ \\
GM & $50 \mathrm{c}$ & $69 \mathrm{bc}$ & $28.0 \mathrm{~b}$ & $7.5 \mathrm{c}$ \\
FYM & $36 \mathrm{~b}$ & $63 \mathrm{ab}$ & $32.1 \mathrm{~b}$ & $8.5 \mathrm{bc}$ \\
PM & $30 \mathrm{a}$ & $55 \mathrm{a}$ & $38.7 \mathrm{a}$ & $11.9 \mathrm{a}$ \\
COF & $52 \mathrm{c}$ & $76 \mathrm{~cd}$ & $32.1 \mathrm{~b}$ & $6.6 \mathrm{c}$ \\
Lsd & 5 & 10 & 5.97 & 2.9 \\
CV\% & 6.5 & 8.5 & 10.4 & 19.6 \\
Grand mean & 44 & 67 & 32.4 & 8.5
\end{tabular}

Treatments: C, control; CF, chemical fertilizer; VC, vermi-compost; GM, goat manure; FYM, farm-yard manure; PM, poultry manure; COF, commercial organic fertilizer (MAXO). The means were seperated by using Least Significant Difference (lsd) at $5 \%$ level of significane. The treatments with same letter(s) are nonsignificant to each other.

\section{SPAD}

SPAD reading is considered to be highly corelated to the chlorophyll content of the leaves. SPAD reading was most prominent in chemical fertilizer, which was superior to all the treatments except vermicomost.

\section{Stem diameter}

Poultry manure produced the largest stem diameter, which was significantly larger than rest of the treatment except that of vermicompost. Vermicompost, however, was at par with both poultry manure and FYM, but significantly robust than the other treatments. The overall stem diameter and other vegetative features gained by the use of organic sources of plant nutrients thereby can be correlated to higher dry matter accumulation as compared to tall succelent plants resulting due to use of chemical sources.

\section{Number of branches}

Vermicompost produced the significantly higher number of branches than the other treatments except poultry manure. Further, poultry manure was superior to all other treatments but was at par with goat manure, which was found to be superior than control in producing branches. Control was found to be at par with chemical fertilizer, FYM and commercial organic fertilizer.

\section{Average fruit weight}

Vermicompost produced the significantly heavier fruits than the other treatments except poultry manure. Further, poultry manure was superior to all other treatments but was at par with FYM. FYM proved to be superior in terms of fruit weight than chemical fertilizer and commercial organic fertilizer, but similar to goat manure. Moreover, goat manure, chemical and organic fertilizers were similar among eachother, but superior to control (Table 2).

\section{Yield per plant}

Use of vermicompost and poultry manure showed superior yielding caliber in sweet pepper producing yield superior than control and commercial organic fertilizer. The other treatments however were similar to each other in their yielding capacity.

Chemical fertilizers tend to provide the plant nutrients readily 
and encourage vegetative growth, thereby, delaying the flowering phenomenon in sweet pepper. Moreover, use of bulky organic manures acclerated the flowering than commercial organic fertilizer, chemical fertilizer and control was also reported by Abu-Zahara ${ }^{6}$ suggesting the phenomenon to be developed by the increased temperature in the rhizosphere due to decomposition of those substrates.

Positive response of vermi-compost in different growth parameters of sweet pepper is due to fact that it increases the microbial population and also provides the source of energy to sustain them and remain active. ${ }^{7}$ It increases the plant growth and yield by providing nutrients in the available form as compared to other organic manures and conventional inorganic fertilizers. Vermi-compost retains nutrients for long time while the conventional compost fails to deliver the required amount of macro and micronutrient including the vital NPK to plants in shorter time. Euras ${ }^{8}$ reported that the vermin-compost is proving to be highly nutritive organic fertilizer and more powerful growth promoter over the conventional composts. The Vermi composting accelerates the rate of decomposition of the organic matter, alters the physical and chemical properties of the material, and lowers the C: $\mathrm{N}$ ratio, leading to a rapid humification process in which the unstable organic matter is fully oxidized. ${ }^{9}$ Application of vermin-compost to soils increased their microbial biomass and dehydrogenase activity. ${ }^{10}$ This increase in microbial mass and dehydrogenase activity helps in nitrogen fixation and increase the availability to the crop and boost up the growth and development. Rosen \& Bierman ${ }^{11}$ reported it improves soil structure or tilt and increases its water holding capacity.

Table 2 Effect of various treatments on yield attributes and yield of sweet pepper

\begin{tabular}{|c|c|c|c|c|}
\hline Treatment & $\begin{array}{l}\text { Number of } \\
\text { branches }\end{array}$ & Average fruit weight (g) & SPAD & Yield per plant (g) \\
\hline $\mathbf{C}$ & $7 \mathrm{~d}$ & $21.4 \mathrm{e}$ & $29.8 \mathrm{~cd}$ & $62.3 \mathrm{c}$ \\
\hline $\mathbf{C F}$ & $9 \mathrm{~cd}$ & $27.0 \mathrm{~d}$ & $51.1 \mathrm{a}$ & $91.7 \mathrm{abc}$ \\
\hline $\mathbf{V C}$ & $15 \mathrm{a}$ & $36.6 \mathrm{a}$ & $49.9 \mathrm{ab}$ & $126.7 \mathrm{a}$ \\
\hline GM & $11 \mathrm{bc}$ & $28.1 \mathrm{~cd}$ & $39.5 \mathrm{bc}$ & $99.3 \mathrm{abc}$ \\
\hline FYM & $10 \mathrm{~cd}$ & $32.0 \mathrm{bc}$ & $26.0 \mathrm{~d}$ & $105.3 \mathrm{ab}$ \\
\hline PM & $14 \mathrm{ab}$ & $35.9 \mathrm{ab}$ & $39.5 \mathrm{bc}$ & $120.3 \mathrm{a}$ \\
\hline $\mathrm{COF}$ & $9 \mathrm{~cd}$ & $26.3 \mathrm{~d}$ & $40.6 \mathrm{~b}$ & $81.7 \mathrm{bc}$ \\
\hline Lsd & 3.3 & 4.5 & 10.4 & 38.4 \\
\hline CV\% & 17.1 & 8.8 & 14.8 & 13.8 \\
\hline Grand mean & 11 & 29.6 & 39.5 & 98.2 \\
\hline
\end{tabular}

Treatments: C, control; CF, chemical fertilizer; VC, vermi-compost; GM, goat manure; FYM, farm-yard manure; PM, poultry manure; COF, commercial organic fertilizer (MAXO). The means were seperated by using Least Significant Difference (Isd) at $5 \%$ level of significane. The treatments with same letter(s) are nonsignificant to each other.

\section{Conclusion}

The experiment showed that the use of vermicompost was better for sweet pepper growth and development as compared to other organic manures and chemical fertilizers used in the experiment. The use of commercially available organic fertilizer was seen to be a poor choice. The use of other organic manures and chemical fertilizer were similar concerning the growth and yield of sweet pepper. The use of high cost-chemical fertilizer can be readily substituted by farmproduced organic sources of plant nutrients and thus aid in sustainable and efficient resource use. However, it is important to note the better results of vermi-compost as the source of organic manure in sweet pepper.

\section{Acknowledgements}

None.

\section{Conflict of interest}

The author declares no conflict of interest.

\section{References}

1. Safford WE. Our heritage from the American Indians. Journal of the Illinois State Archaeological Society. 1926;4(1):405-410.

2. Flores P, Hellin P, Fenoll J. Effect of manure and mineral fertilization on pepper nutritional quality. Journal of Science, Food and Agriculture. 2009;89(9):1581-1586.

3. Jadczak D, Grzeszczuk M, Kosecka D. Quality characteristics and content of mineral compounds in fruit of some cultivars of sweet pepper (Capsicum annuиm L.). J Elementol. 2010;15(3):509-515.

4. Bhattarai DR. What is capsicum? Bikash Today. Gramin Bikash Media, Kathmandu, Nepal; 2010.

5. Stockdale EA, Lampkin NH, Hovi M, et al. Agronomic and environmental implications of organic farming systems. Advances in Agronomy. 2001;70:260-306.

6. Abu-Zahra TR. Vegetative, flowering and yield of sweet pepper as influenced by agricultural practices. Middle East Journal of Science Research. 2012;11(9):1220-1225. 
7. Ghimire S, Shakya SM, Shrivastava A. Sweet pepper production using different nitrogen sources in subtropical climate. Journal of Agriculture and Food Science. 2013;1(1):6-10.

8. Euras A. Vermi culture can promote sustainable agriculture and completely replace chemical agriculture: Some experimental evidences by studies on potted and farmed cereal and vegetable crop. Journal of Agriculture and Environmental Science. 2009;5(5):1-55.

9. Albanell E, Plaixats J, Cabrero T. Chemical changes during vermicomposting (Eisenia fetida) of sheep manure mixed with cotton industrial wastes. Biology and Fertility of Soils. 1988;6(3):266-269.
10. Arancon NQ, Edwards CA, Bierman P, et al. Effects of vermin-composts on growth and marketable fruits of field-grown tomatoes, peppers and strawberries. Pedobiologia. 2003;47:731-735.

11. Rosen CJ, Bierman PM. Using manure and compost as nutrient source for fruit and vegetable crops. Department of soil, water and climate. USA: University of Minnesota; 2005. 